\title{
The Potential Role of Polyphenols in Modulating Mitochondrial Bioenergetics within the Skeletal Muscle: A Systematic Review of Preclinical Models
}

\author{
Sinenhlanhla X. H. Mthembu ${ }^{1,2}{ }^{\mathbb{D}}$, Phiwayinkosi V. Dludla ${ }^{1}$, Khanyisani Ziqubu ${ }^{3}$, Tawanda M. Nyambuya ${ }^{4,5} \mathbb{D}$ \\ Abidemi P. Kappo ${ }^{6}\left(\mathbb{D}\right.$, Evelyn Madoroba ${ }^{2}$, Thembeka A. Nyawo ${ }^{1,7}$, Bongani B. Nkambule ${ }^{5}$, Sonia Silvestri ${ }^{8} \mathbb{D}$, \\ Christo J. F. Muller 1,2,7 (D) and Sithandiwe E. Mazibuko-Mbeje ${ }^{3, *(1)}$
}

1 Biomedical Research and Innovation Platform, South African Medical Research Council, Tygerberg 7505, South Africa; sinenhlanhla.Mthembu@mrc.ac.za (S.X.H.M.); Phiwayinkosi.dludla@mrc.ac.za (P.V.D.); Thembeka.Nyawo@mrc.ac.za (T.A.N.); christo.muller@mrc.ac.za (C.J.F.M.)

2 Department of Biochemistry and Microbiology, University of Zululand, KwaDlangezwa 3886, South Africa; MadorobaE@unizulu.ac.za

3 Department of Biochemistry, Faculty of Natural and Agricultural Sciences, Mafikeng Campus, North West University, Private Bag X 2046, Mmabatho 2735, South Africa; ziqubukhanyisani@gmail.com

check for updates

Citation: Mthembu, S.X.H.; Dludla, P.V.; Ziqubu, K.; Nyambuya, T.M.; Kappo, A.P.; Madoroba, E.; Nyawo, T.A.; Nkambule, B.B.; Silvestri, S.; Muller, C.J.F.; et al. The Potential Role of Polyphenols in Modulating Mitochondrial Bioenergetics within the Skeletal Muscle: A Systematic Review of Preclinical Models. Molecules 2021, 26, 2791. https://doi.org/10.3390/ molecules26092791

Academic Editors: Letizia Bresciani and Anna Tresserra-Rimbau

Received: 5 March 2021

Accepted: 11 April 2021

Published: 10 May 2021

Publisher's Note: MDPI stays neutral with regard to jurisdictional claims in published maps and institutional affiliations.

Copyright: (c) 2021 by the authors. Licensee MDPI, Basel, Switzerland. This article is an open access article distributed under the terms and conditions of the Creative Commons Attribution (CC BY) license (https:/ / creativecommons.org/licenses/by/ $4.0 /)$.
4 Department of Health Sciences, Faculty of Health and Applied Sciences, Namibia University of Science and Technology, Windhoek 9000, Namibia; mnyambuya@nust.na

5 School of Laboratory Medicine and Medical Sciences, College of Health Sciences, University of KwaZulu-Natal, Durban 4000, South Africa; nkambuleb@ukzn.ac.za

6 Department of Biochemistry, Faculty of Science, Kingsway Campus, University of Johannesburg, Auckland Park 2006, South Africa; akappo@uj.ac.za

7 Division of Medical Physiology, Faculty of Health Sciences, Stellenbosch University, Tygerberg 7505, South Africa

8 Department of Life and Environmental Sciences, Polytechnic University of Marche, 60131 Ancona, Italy; s.silvestri@univpm.it

* Correspondence: 36588296@nwu.ac.za; Tel.: +27-18-399-2854

Abstract: Polyphenols are naturally derived compounds that are increasingly being explored for their various health benefits. In fact, foods that are rich in polyphenols have become an attractive source of nutrition and a potential therapeutic strategy to alleviate the untoward effects of metabolic disorders. The last decade has seen a rapid increase in studies reporting on the bioactive properties of polyphenols against metabolic complications, especially in preclinical models. Various experimental models involving cell cultures exposed to lipid overload and rodents on high fat diet have been used to investigate the ameliorative effects of various polyphenols against metabolic anomalies. Here, we systematically searched and included literature reporting on the impact of polyphenols against metabolic function, particularly through the modulation of mitochondrial bioenergetics within the skeletal muscle. This is of interest since the skeletal muscle is rich in mitochondria and remains one of the main sites of energy homeostasis. Notably, increased substrate availability is consistent with impaired mitochondrial function and enhanced oxidative stress in preclinical models of metabolic disease. This explains the general interest in exploring the antioxidant properties of polyphenols and their ability to improve mitochondrial function. The current review aimed at understanding how these compounds modulate mitochondrial bioenergetics to improve metabolic function in preclinical models on metabolic disease.

Keywords: polyphenols; skeletal muscle; mitochondrial function; insulin resistance; metabolic syndrome

\section{Introduction}

Polyphenols are naturally derived compounds that are widely studied for their health benefits [1]. In fact, polyphenols can be grouped into four major categories, which include 
flavonoids, phenolic acids, stilbenes, and lignans. Flavonoids, one of the larger classes of polyphenols, can be further grouped into flavones, flavonols, flavanols, flavanones, isoflavones, proanthocyanidins, and anthocyanins [2]. Chemically, flavonoids have the universal structure of a 15-carbon skeleton, containing two phenyl rings and a heterocyclic ring. This carbon structure can be abbreviated as C6-C3-C6 [2]. Consumed food or beverage sources such as tea, fruits, and vegetables are known to contain high levels of polyphenols which include aspalathin, catechin, hesperetin, cyanidin, proanthocyanidins, quercetin, and rutin [3]. There is a significant interest in understanding the bioactivities of these compounds, with the PubMed search showing that over 4599 relevant records can be accessed to date, and a considerable growth in publications has been seen in the last decade [4]. In addition, many plants that are rich in polyphenols such as Aspalathus linearis "rooibos tea plant" [5] and Camellia sinensis "tea plant" [6] are widely investigated for their health benefits such as improving cardiovascular function and combating cancer $[7,8]$. In fact, our group has been actively involved in understanding the therapeutic effects of rooibos, including assessing its ameliorative effects against diverse metabolic complications $[9,10]$. Accumulatively, we have shown that polyphenolic compounds such as aspalathin, isoorientin, and rutin can activate various physiological pathways such as protein kinase B (AKT) and AMP-activated protein kinase (AMPK) to improve insulin signaling and regulate energy metabolism [11,12]. Likewise, polyphenolic compounds such as gallic acid and catechins can reduce body weight and attenuate metabolic abnormalities, especially scavenging free radical species through their abundant antioxidant properties [13].

Indeed, the bioactivity of polyphenols has been mainly attributed to their abundant antioxidant properties, which have been linked with improved metabolism, reduced inflammation, and ameliorating oxidative stress [14]. Notably, inflammation and oxidative stress are some of the key destructive components that are implicated in the development of metabolic anomalies and deteriorated metabolic health. Inflammation is characterized by enhanced pro-inflammatory cytokines such as tumor necrosis factor- $\alpha$ (TNF- $\alpha$ ) and interleukin-6 (IL-6) [15]. On the other hand, oxidative stress arises because of overproduction of reactive oxygen species (ROS) that trigger suppression of intracellular antioxidant such as glutathione, superoxide dismutase, catalase, and thioredoxins [16]. Recently, impaired mitochondrial dysfunction has been reported to play an important role in the generation of oxidative stress through the altered actions of the electron transport chain [17]. For example, enhanced substrate delivery including free fatty acids (FFAs), especially under the conditions of metabolic syndrome, can impede the actions of the mitochondrial electron transport chain, resulting in the leakage of electrons and the overproduction of ROS. In fact, a few studies have correlated impaired mitochondrial bioenergetics with the generation of oxidative stress and reduced metabolic function [18]. As a result, many studies have targeted the main energy regulating tissues with abundant mitochondria, such as the skeletal muscle, to understand how increased substrate availability reduces or affects metabolic function $[19,20]$. Similarly, several studies have been published focusing on understanding how polyphenols affects mitochondrial bioenergetics in conditions of metabolic stress [21,22]. Currently, there is limited reviews on this topic or those targeting the modulation effect of polyphenols on skeletal muscle physiology. Thus, the current study aims to systematically extract and discuss relevant literature on the impact of polyphenols and plants rich in these compounds on their ameliorative effects against metabolic complications by targeting mitochondrial bioenergetics within the skeletal muscle.

\section{Methodology for Study Selection and Inclusion}

\subsection{Data Sources and Search Strategies}

The present review included preclinical trials obtained from a comprehensive search conducted on electronic databases, such as PubMed, from date of conception up to 30 December 2020. Two investigators, SXHM and KZ, independently conducted the search process and evaluated studies for eligibility and a third reviewer (PVD) was consulted 
in cases of disagreements. The systematic search was conducted using medical subject heading (MeSH) terms such as "polyphenols", "bioactive compounds", "mitochondria", "metabolic syndrome", and "skeletal muscle". The search was restricted to English only. Mendeley reference manager version 1.19.4-dev2 software (Elsevier, Amsterdam, The Netherlands) was used to identify any duplicated studies.

\subsection{Inclusion and Exclusion Criteria}

This review includes in vitro and in vivo studies reporting on the impact of polyphenols on mitochondrial bioenergetics and related complications in skeletal muscle. In this review, only preclinical studies reporting on evidence involving skeletal muscle, polyphenols, and/or bioactive compounds and mitochondrial bioenergetics were included. This review is focused on better understanding the importance of polyphenols and bioactive compounds on pre-clinical studies, therefore human studies, books, letters, case reports, and reviews were excluded.

\subsection{Data Extraction and Representation}

Studies from the initial search on PubMed were screened for eligibility, they were then subsequently evaluated by full-text screening. Data was extracted by two investigators (SXHM and KZ) independently with (PVD) as a third investigator in case of any disagreements. Data extraction was performed in the following format: polyphenols/bioactive compounds, experimental model, effective dose, and intervention period, and main findings and author details (name and year of publication).

\section{Results}

\subsection{An Overview of Results}

The primary outcome of the study was to evaluate the impact of polyphenols on mitochondrial bioenergetics, oxidative stress, and/or any other metabolic complications within the skeletal muscle. Figure 1 shows the flow chart of the study selection. Briefly, 7 studies were initially identified; however, after screening and reviewing the titles and abstracts, only 40 studies were eligible for the full-text assessment. After reviewing the full-text articles, a total of 25 studies were irrelevant to the topic of interest. Therefore, 15 met the inclusion criteria and were discussed within the review.

\subsection{A Brief Overview on Polyphenolic Compounds and Their Impact on Mitochondrial Bioenergetics and Linked Metabolic Function in Various Preclinical Models}

In addition to giving a brief background on the source and bioavailability profile, both in vivo and in vitro studies are discussed based on each polyphenolic compound, systematically extracted from the literature, as represented in Tables 1 and 2. 


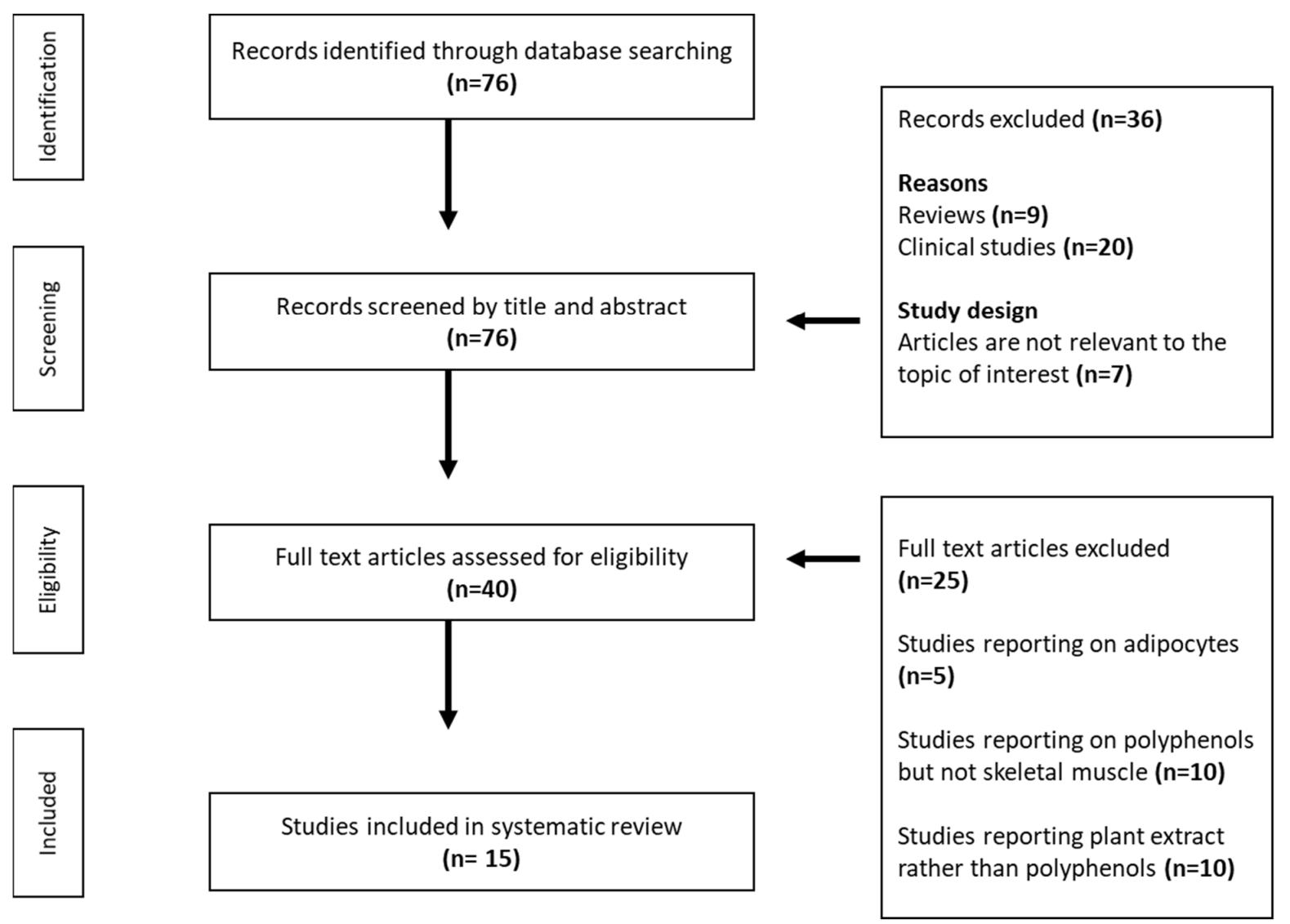

Figure 1. Flow chart representing the study selection procedure.

Table 1. A summary of the in vitro studies reporting on the impact of polyphenols on mitochondrial bioenergetics and metabolic function within the skeletal muscle.

\begin{tabular}{|c|c|c|c|c|}
\hline Polyphenols & Experimental Model & $\begin{array}{l}\text { Effective Dose and } \\
\text { Duration }\end{array}$ & Main Findings & Ref. \\
\hline \multirow{4}{*}{ Resveratrol } & $\mathrm{C} 2 \mathrm{C} 12$ myoblast & $25 \mu \mathrm{M}$ resveratrol for $24 \mathrm{~h}$ & $\begin{array}{l}\text { Enhanced mitochondrial function and biogenesis } \\
\text { in a NAD-dependent deacetylase sirtuin- } 1 \\
\text { (SIRT1)-dependent manner. This included } \\
\text { increasing ATP content and peroxisome } \\
\text { proliferator-activated receptor } \gamma \text { coactivator } 1-\alpha \\
\text { (PGC1 } \alpha \text { ) protein expression }\end{array}$ & [21] \\
\hline & C2C12 myotubes & $\begin{array}{c}20 \text { or } 50 \mu \mathrm{M} \text { resveratrol for } \\
6 \text { or } 24 \mathrm{~h} \text {, respectively }\end{array}$ & $\begin{array}{l}\text { High dose reduced ATP production and activated } \\
\text { AMP-activated protein kinase (AMPK) } \\
\text { phosphorylation. Resveratrol induced } \\
\text { overexpression of SIRT1 decreased PGC1 } \alpha \\
\text { acetylation and PGC1 } \alpha \text { coactivator activity }\end{array}$ & [23] \\
\hline & C2C12 myoblast & $\begin{array}{c}20,40,60 \mu \mathrm{M} \text { resveratrol } \\
\text { for } 24 \mathrm{~h}\end{array}$ & $\begin{array}{c}\text { Increased miR-27b expression and mtDNA, which } \\
\text { improved mitochondrial function and glucose } \\
\text { uptake in a Sirt1-dependent manner }\end{array}$ & [24] \\
\hline & $\begin{array}{l}\text { Palmitate-induced } \\
\text { mitochondrial } \\
\text { dysfunction C2C12 } \\
\text { myotubes }\end{array}$ & $25 \mu \mathrm{M}$ resveratrol for $24 \mathrm{~h}$ & $\begin{array}{l}\text { Ameliorated mitochondrial dysfunction and } \\
\text { oxidative stress as evident by improved mtDNA } \\
\text { content and increased expression of mitochondrial } \\
\text { biogenesis-r elated protein including PGC1 } \alpha \text {, } \\
\text { mitochondrial transcription factor (TFAM), } \\
\text { mitofusin } 2 \text { (mfn2), and drosophila melanogaster } \\
\text { (drp1), as well as reduced ROS production }\end{array}$ & [17] \\
\hline (S)-[6]-gingerol & L6 rat myotubes & $\begin{array}{c}\text { 50, } 100 \text { and } 150 \mu \mathrm{M} \\
\text { (S)-[6]-gingerol for } 24 \mathrm{~h}\end{array}$ & $\begin{array}{l}\text { Activated AMPK } \alpha \text {, which was accompanied by an } \\
\text { increased mitochondrial content number, as well } \\
\text { as an improved gene expression of PGC- } 1 \alpha\end{array}$ & [25] \\
\hline $\begin{array}{l}\text { Naringenin and } \\
\text { quercetin }\end{array}$ & $\begin{array}{l}\text { Palmitate-induced } \\
\text { insulin resistance L6 } \\
\text { myotubes }\end{array}$ & $\begin{array}{l}75 \mu \mathrm{M} \text { naringenin or } 750 \\
\mathrm{mM} \text { quercetin for } 16 \mathrm{~h}\end{array}$ & $\begin{array}{l}\text { Increased glucose transporter (GLUT) } 4 \\
\text { translocation, AMPK phosphorylation, and SIRT1 } \\
\text { and PGC1 } \alpha \text { expression }\end{array}$ & [26] \\
\hline
\end{tabular}


Table 1. Cont.

\begin{tabular}{|c|c|c|c|c|}
\hline Polyphenols & Experimental Model & $\begin{array}{l}\text { Effective Dose and } \\
\text { Duration }\end{array}$ & Main Findings & Ref. \\
\hline Pinosylvin & Rats L6 myotubes & $\begin{array}{c}20 \text { or } 60 \mu \mathrm{M} \text { pinosylvin } \\
\text { for } 24 \mathrm{~h}\end{array}$ & $\begin{array}{l}\text { Pinosylvin activated SIRT1 in vitro and } \\
\text { stimulated glucose uptake through the } \\
\text { activation of AMPK }\end{array}$ & [27] \\
\hline Icariin & C2C12 myocytes & $\begin{array}{l}20,40,80 \mu \mathrm{g} / \mathrm{mL} \text { icariin } \\
\text { for } 24 \mathrm{~h}\end{array}$ & $\begin{array}{c}\text { Increased irisin/fibronectin type lll domain } \\
\text { containing } 5 \text { (FNDC5), PGC1 } \alpha \text { gene expression, } \\
\text { and dose-dependently increased AMPK } \\
\text { phosphorylation }\end{array}$ & [28] \\
\hline $\begin{array}{l}\text { Flavonoids } \\
\text { (mulberry.) }\end{array}$ & $\begin{array}{l}\text { Palmitate-induced } \\
\text { insulin resistance L6 } \\
\text { myotubes }\end{array}$ & $\begin{array}{l}100 \mathrm{nmol} / \mathrm{L} \text { insulin, } 0.75 \\
\mathrm{mmol} / \mathrm{L} \text { Palmitic acid } \\
(\mathrm{PA}) \text { and MLF }(5,10,20 \\
40 \text { and } 80 \mu \mathrm{g} / \mathrm{mL}) \text { for } 24 \mathrm{~h}\end{array}$ & $\begin{array}{l}\text { MLF and metformin significantly ameliorated } \\
\text { glucose uptake by activating AMPK and } \\
\text { reduced ROS production in L6 cells. } \\
\text { Furthermore, MLF improved mitochondrial } \\
\text { function by increasing the expression of PGC1 } \alpha\end{array}$ & [29] \\
\hline
\end{tabular}

Table 2. A summary of in vivo studies reporting on the impact of polyphenols on mitochondrial bioenergetics and metabolic function within the skeletal muscle.

\begin{tabular}{|c|c|c|c|c|}
\hline Polyphenols & Experimental Model & $\begin{array}{c}\text { Effective Dose and } \\
\text { Duration }\end{array}$ & Main Findings & Ref. \\
\hline \multirow{7}{*}{ Resveratrol } & $\begin{array}{l}\text { High-fat diet (HFD) } \\
\text { induced obese C57BL/6J } \\
\text { mice }\end{array}$ & $\begin{array}{c}400 \mathrm{mg} / \mathrm{kg} / \text { day resveratrol } \\
\text { for } 15 \text { weeks }\end{array}$ & $\begin{array}{l}\text { Increased oxygen consumption was accompanied by } \\
\text { regulation of the genes for mitochondrial biogenesis } \\
\text { such as peroxisome proliferator-activated receptor } \gamma \\
\text { coactivator } 1 \alpha(\mathrm{PGC} 1 \alpha) \text { acetylation and activity }\end{array}$ & [30] \\
\hline & $\begin{array}{l}\text { HFD-fed Sprague Dawley } \\
\text { rats }\end{array}$ & $\begin{array}{l}100 \mathrm{mg} / \mathrm{kg} \text { b.w./day } \\
\text { resveratrol for } 8 \text { weeks }\end{array}$ & $\begin{array}{l}\text { Reduced intramuscular lipid accumulation and } \\
\text { ameliorated insulin resistance, in part by enhancing } \\
\text { NAD-dependent deacetylase sirtuin } 1 \text { (SIRT1) activity, } \\
\text { increasing mitochondrial biogenesis and } \beta \text {-oxidation }\end{array}$ & [14] \\
\hline & $\begin{array}{l}\text { Catch-up growth-induced } \\
\text { insulin resistance Sprague } \\
\text { Dawley rats }\end{array}$ & $\begin{array}{l}100 \mathrm{mg} / \mathrm{kg} \mathrm{b.w./day} \\
\text { resveratrol treatment for } 4 \\
\text { and } 8 \text { weeks }\end{array}$ & $\begin{array}{c}\text { Enhanced SIRT1 activity and improved } \\
\text { mitochondrial number and insulin sensitivity, as well } \\
\text { as decreased levels of reactive oxygen species and } \\
\text { restored antioxidant enzyme activities, including } \\
\text { superoxide dismutase (SOD), catalase (CAT), and } \\
\text { glutathione peroxidase (GPx) }\end{array}$ & [31] \\
\hline & C57/BL6J mice & $\begin{array}{l}25-30 \mathrm{mg} / \mathrm{kg} \text { b.w / day (low } \\
\text { dose) and } 215-230 \mathrm{mg} / \mathrm{kg} \\
\text { b.w / day (high dose) } \\
\text { resveratrol for } 8 \text { months }\end{array}$ & $\begin{array}{c}50 \mu \mathrm{M} \text { dose significantly decreased ATP levels early } \\
\text { as } 1 \mathrm{~h} \text { after treatment and activated AMPK } \\
\text { independently of SIRT1. At } 25 \mu \mathrm{M} \text { resveratrol } \\
\text { increased mitochondrial function by increased } \\
\text { expression of PGC1 } \alpha, \text { PGC1 } \beta \text {, and TFAM including } \\
\text { the transcription factor B2 (TFB2M) in a } \\
\text { SIRT1-dependent manner. This was also supported } \\
\text { by an increase on mtDNA content. Furthermore, } \\
\text { resveratrol AMP-activated protein kinase (AMPK) } \\
\text { and increased NAD+ levels }\end{array}$ & [21] \\
\hline & $\begin{array}{l}\text { HFD-induced insulin } \\
\text { resistance Sprague Dawley } \\
\text { rats }\end{array}$ & $\begin{array}{c}100 \mathrm{mg} / \mathrm{kg} / \text { day resveratrol } \\
\text { for } 8 \text { weeks }\end{array}$ & $\begin{array}{l}\text { Ameliorated insulin resistance through increased } \\
\text { SIRT1 and SIRT3 expressions and elevated mtDNA } \\
\text { and mitochondrial biogenesis. This included } \\
\text { enhancing mitochondrial antioxidant enzymes } \\
\text { including SOD, CAT, and GPx }\end{array}$ & [32] \\
\hline & HFD-fed C57BL/6J mice & $\begin{array}{l}0.02,0.04 \text {, and } 0.06 \% \\
\text { resveratrol for } 12 \text { weeks }\end{array}$ & $\begin{array}{l}\text { Reduced the plasma insulin and glucose } \\
\text { concentrations, which were accompanied by an } \\
\text { increased miR-27b overexpression, which improved } \\
\text { mitochondrial function in a Sirt1-dependent manner }\end{array}$ & [24] \\
\hline & $\begin{array}{l}\text { HFD-induced sarcopenic } \\
\text { obesity Sprague Dawley } \\
\text { rats }\end{array}$ & $\begin{array}{c}0.4 \% \text { resveratrol for } 20 \\
\text { weeks }\end{array}$ & $\begin{array}{l}\text { Ameliorated mitochondrial dysfunction and } \\
\text { oxidative stress via the serine-threonine kinase LKB1 } \\
\text { (PKA/LKB1)/AMPK pathway. This was evident by } \\
\text { increased activity of complexes I, II, and IV, and } \\
\text { raised PGC1 } \alpha \text {, TFAM, and mfn2, as well as decreased } \\
\text { drp1 expression. Moreover, there was an increase in } \\
\text { the total antioxidative capability (T-AOC), SOD, GPx, } \\
\text { MDA, and carbonyl protein }\end{array}$ & [17] \\
\hline
\end{tabular}


Table 2. Cont.

\begin{tabular}{|c|c|c|c|c|}
\hline Polyphenols & Experimental Model & $\begin{array}{c}\text { Effective Dose and } \\
\text { Duration }\end{array}$ & Main Findings & Ref. \\
\hline \multirow[b]{2}{*}{ Proanthocyanidins } & $\begin{array}{l}\text { Obese Zucker fatty rats } \\
\qquad(f a / f a)\end{array}$ & $\begin{array}{l}35 \mathrm{mg} / \mathrm{kg} \text { b.w. / day } \\
\text { proanthocyanidins } 68 \text { days }\end{array}$ & $\begin{array}{l}\text { Decreased citrate synthase activity and oxidative } \\
\text { phosphorylation complexes I and II levels and Nrf1 } \\
\text { gene expression, which in turn reduced reactive } \\
\text { oxygen species (ROS) production }\end{array}$ & [33] \\
\hline & $\begin{array}{l}\text { Diet-induced obese } \\
\text { Wistar rats }\end{array}$ & $\begin{array}{l}25 \mathrm{mg} / \mathrm{kg} \text { b.w./day } \\
\text { proanthocyanidins for } 21 \\
\text { days }\end{array}$ & $\begin{array}{l}\text { Reduced insulin resistance, improved mitochondrial } \\
\text { respiration, mitochondrial oxidative capacity, and } \\
\text { fatty acid oxidation as evident by increased } \\
\text { mitochondrial enzymatic activities, AMPK } \\
\text { phosphorylation, and the expression of peroxisome } \\
\text { proliferator-activated receptor } \alpha(\text { Ppar } \alpha) \text { and UCP2 }\end{array}$ & [34] \\
\hline $\begin{array}{l}\text { Flavan 3-ols fraction } \\
\text { derived from cocoa } \\
\text { powder }\end{array}$ & C57BL/J mice & $\begin{array}{l}50 \mathrm{mg} / \mathrm{kg} \text { b.w./day } \\
\text { flavan-3-ols for } 2 \text { weeks }\end{array}$ & $\begin{array}{c}\text { Enhanced lipolysis and promoted mitochondrial } \\
\text { biogenesis marked by increased carnitine } \\
\text { palmitoyltransferase } 2 \text { (CPT2) expression and } \\
\text { mitochondria copy number }\end{array}$ & [35] \\
\hline $\begin{array}{l}\text { Naringenin and } \\
\text { quercetin }\end{array}$ & $\begin{array}{l}\text { High-fructose } \\
\text { diet-induced insulin } \\
\text { resistance Wistar rats }\end{array}$ & $\begin{array}{l}50 \mathrm{mg} / \mathrm{kg} \text { b.w./day } \\
\text { naringenin and quercetin for } \\
6 \text { weeks }\end{array}$ & $\begin{array}{l}\text { Both naringenin and quercetin reduced the plasma } \\
\text { glucose and insulin levels accompanied by a } \\
\text { significant increase in SIRT1 and PGC1 } \alpha \text { expression, } \\
\text { AMPK phosphorylation, and glucose transporter type } \\
4 \text { (GLUT4) translocation }\end{array}$ & [26] \\
\hline Icariin & C57BL/6 mice & $\begin{array}{c}10 \text { or } 40 \mathrm{mg} / \mathrm{kg} / \text { day icariin } \\
\text { for } 14 \text { days }\end{array}$ & $\begin{array}{l}\text { Decrease in body weight gain by increasing FNDC5, } \\
\text { PGC-1 } \alpha \text {, and p-AMPK expression levels }\end{array}$ & [28] \\
\hline Flavonoids & $\begin{array}{l}\text { Type } 2 \text { diabetic }(d b / d b) \\
\text { mice }\end{array}$ & $\begin{array}{c}180 \mathrm{mg} / \mathrm{kg} \text { flavonoids for } 7 \\
\text { weeks }\end{array}$ & $\begin{array}{l}\text { Ameliorated insulin resistance and symptoms } \\
\text { associated with diabetes through increased p-AMPK } \\
\text { and PGC1 } \alpha \text {, raised m-GLUT4 and T-GLUT4 protein } \\
\text { expression, and improved mitochondrial function }\end{array}$ & [29] \\
\hline
\end{tabular}

\subsubsection{Resveratrol}

Resveratrol (3,5,4'-trans-trihydroxystilbene, Figure 2$)$ is a polyphenolic phytoalexin also belonging to the stilbene family that is abundant in grape skin and seeds, but is also found in various types of plant foods such as berries, peanuts, and wine [36]. This polyphenol is widely available and it is synthesized by more than 70 species of plants [37]. Although it exhibits low bioavailability and solubility [37], experimental data on resveratrol have been widely reviewed, and it has shown potential benefits for human health and exhibits protective effects against metabolic complications such as inflammation, oxidative stress, and aging. Moreover, resveratrol has shown promising properties in ameliorating complications linked with diseases such as diabetes and obesity. Evidence from studies by Price et al. [21] and Higashida et al. [23] demonstrated that resveratrol enhanced mitochondrial function and biogenesis in a SIRT1-dependent manner, and this was consistent with improved mtDNA content in palmitate-treated skeletal muscle cells and HFD-fed mice. This includes increasing the protein expression of PGC1 $\alpha$ and other mitochondrial functional genes such as TFAM, $\mathrm{mfn} 2$, and drp1, as well as the activity of mitochondrial complexes I-V in skeletal muscle cells [21,23,24].<smiles>Oc1ccc(/C=C/c2cc(O)cc(O)c2)cc1</smiles>

Figure 2. The chemical structure of resveratrol. A polyphenol commonly found in various plant food such as berries and wines [38].

Furthermore, in vivo studies suggest that resveratrol exhibits strong antioxidant properties in improving skeletal muscle function in various HFD-induced insulin-resistant 
models $[17,31,32]$. These effects were shown by a decreased level of ROS, a strong indicator of oxidative stress, which occurred concomitant with restored antioxidant enzyme activities, including SOD, CAT, and GPx. Furthermore, Huang et al. [17] demonstrated that resveratrol ameliorated insulin resistance in HFD-induced obese Sprague Dawley rats by reducing intramuscular lipid accumulation and enhancing SIRT1 activity. This was, in part, by increasing mitochondrial biogenesis and $\beta$-oxidation in the skeletal muscle of these rats. More evidence included in this review demonstrated that resveratrol increased the phosphorylation of AMPK in the skeletal muscle of both C57/BL6J mice and HFD-induced sarcopenic obesity Sprague Dawley rats $[17,21]$. Overall, resveratrol demonstrates a wide array of benefits in improving metabolic function, in part by effectively regulating energy metabolism and mitochondrial bioenergetics within the skeletal muscle.

\subsubsection{Gingerol}

Gingerol is the primary bioactive phenylpropanoid in the rhizome of ginger (Z. officinale Roscoe; Zingiberaceae) (Figure 3) which is known for its pungent taste and aroma [25]. Ginger is widely used a spice and medicinal herb, highlighting the general interest in the potential health benefits of the bioactive compounds found in this functional food product [39]. Generally, ginger contains pungent phenolic substances known as gingerols, shogaols, paradols, and zingerone [39]. Amongst the constituents of gingerols [6]-gingerol (1-[4'-hydroxy-3'-methoxyphenyl]-5-hydroxy-3-decanone) is the major pharmacologically active component $[40,41]$. This polyphenol is known to display a variety of biological properties, including anticancer [42], antioxidant, anti-inflammatory [43], and antifungal effects [44]. Our literature search showed that this bioactive compound has the potential to enhance mitochondrial function in L6 rat myotubes. Briefly, was is demonstrated that treating normal L6 myotubes with 50, 100, and $150 \mu \mathrm{M}$ (S)-[6]-gingerol for $24 \mathrm{~h}$ could activate $\mathrm{AMPK} \alpha$ and further improve mitochondrial content number and the gene expression of PGC1 $\alpha$ in vitro [45]. Other studies reported that the polyphenol found in ginger could affect metabolic function by reducing blood glucose levels in diabetic animal models and increase glucose uptake in in vitro cultured cells [43,46]. Overall, (S)-[6]-gingerol displays the potential beneficial effects on metabolic function by modulating skeletal muscle mitochondrial function, further suggesting that ginger may be effective in preventing the development of metabolic syndromes. However, additional data is required to confirm its metabolic properties, there has been concern with regard to the low solubility and poor oral absorption of [6]-Gingerol, as reported elsewhere [42]

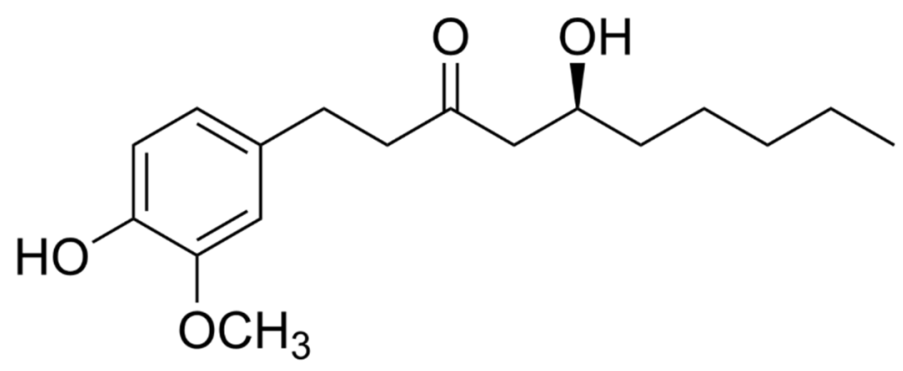

Figure 3. The chemical structure of gingerol. This polyphenol can be generally found as a pungent yellow oil in the ginger rhizome, which can be uniquely identified as a low-melting point crystalline solid [47].

\subsubsection{Quercetin and Naringenin}

Quercetin (3,3', 4',5,7-pentahydroxyflavone, Figure 4) has the ability to exhibit robust antioxidant, anti-apoptosis, and anti-inflammatory properties in different preclinical models [48]. For example, in our literature search, we found that quercetin also has the ability to enhance mitochondrial function [49]. Alternatively, Mutlur Krishnamoorthy, and Carani Venkatraman (2017) [26] showed that treating palmitate-induced insulin resistance L6 myotubes with $750 \mathrm{mM}$ quercetin or $75 \mu \mathrm{M}$ naringenin for $16 \mathrm{~h}$ could improve glucose 
homeostasis and mitochondrial bioenergetics by enhancing GLUT4 translocation, as well as increasing AMPK phosphorylation, and SIRT1 and PGC1 $\alpha$ expression. Apparently, the comparative efficacy of quercetin and naringenin in ameliorating various metabolic anomalies has been subject to increasing preclinical research [22].

Naringenin (2,3-dihydro-5,7-dihydroxy-2-(4-hydroxyphenyl)-4H-1-benzopyran-4-one) is a naturally occurring flavonoid found mostly in some edible fruits, such as citrus species [50]. This flavonoid has been the subject of ongoing research to assess its broad biological effects in preclinical models. For example, this flavonoid has an ability to decrease some lipid peroxidation biomarkers and promote carbohydrate metabolism in preclinical models of metabolic syndrome [26]. Furthermore, naringenin has been shown to have antioxidant and anti-inflammatory effects [51]. A similar effect was observed in an in vivo study, where high fructose diet-induced insulin resistance Wister rats showed decreased mitochondrial function [52]. However, this effect was reversed in rats that were also fed $50 \mathrm{mg} / \mathrm{kg}$ body weight/day naringenin and quercetin for 6 weeks [26]. Here, both naringenin and quercetin reduced the plasma glucose and insulin levels, including GLUT4 translocation, as well as the expression of SIRT1, PGC1 $\alpha$, and AMPK phosphorylation in the insulin resistant Wister rats [26], suggesting that both these polyphenols may improve metabolic function in part by regulating energy metabolism, or by improving glucose uptake and targeting markers of mitochondrial function.<smiles>O=c1c(O)c(-c2ccc(O)c(O)c2)oc2cc(O)cc(O)c12</smiles>

(A)

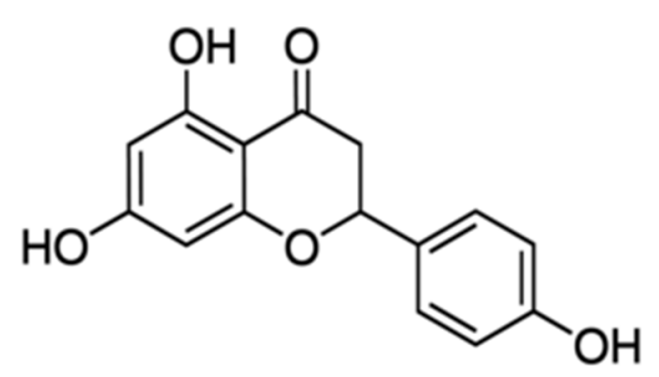

(B)

Figure 4. The chemical structure of quercetin (A) and naringenin (B). These polyphenols are predominant in vegetables, fruits, coffee, and tea in the form of a glycoside [53,54].

\subsubsection{Pinosylvin}

Pinosylvin (3,5-dihydroxy-trans-stilbene, Figure 5) is part of the stilbenoids group, which is a group of polyphenols found in plants, berries, and nuts. These polyphenolic compounds exhibit antimicrobial and antifungal function in plants [55]. Recent information reveals that A stilbene-based compounds might have potential as antiviral agents [56]. Although the widely investigated naturally occurring stilbenoids such as resveratrol are acknowledged, on the other hand, emerging evidence suggests that pinosylvin is gaining attention due to it anti-inflammatory properties [57]. Pinosylvin is a natural polyphenol trans-stilbenoid that is produced by plants as a secondary metabolite to protect against microbes and insects [57]. This polyphenol is mainly found in heartwoods and leaves of Pinus sylvestris. Pinosylvin exerts various biological activities including anti-inflammatory effects [57]. In fact, Modi et al. [27] reported that treating cultured skeletal muscle cells (L6 myotube) with 20 or $60 \mu \mathrm{M}$ pinosylvin for $24 \mathrm{~h}$ activated SIRT1 and stimulated glucose uptake through the activation of AMPK. Although the role of this stilbenoid is emerging, its effects on mitochondrial bioenergetics or function is still very limited. 
<smiles>Oc1cc(O)cc(C=Cc2ccccc2)c1</smiles>

Figure 5. The chemical structure of pinosylvin, a stilbene-based compound found in plants, berries, and nuts [58].

\subsubsection{Icariin}

Icariin is a typical flavonol glycoside also known as the primary active component of Epimedii Herba (Figure 6) [28]. Icariin is commonly known as yin yang hou or goat weed [28]. The extracts of Epimedii Herba have been commonly used in Chinese herbal medicine to treat sexual functions, skeletal muscle deterioration, and other diseases [28,59]. Various pharmacological effects of icariin have been reported, including immunoregulation and vasodilation through the enhanced production of bioactive nitric oxide, as well as showing activity against multiple cardiovascular diseases through antioxidant and antiinflammatory action $[28,60]$. In this review, we found that icariin might have a beneficial effect on the mitochondrial function [28], in part through effective modulation of energy metabolism related pathways/genes such as irisin/FNDC5, PGC1 $\alpha$ gene expression, and dose-dependently increased AMPK phosphorylation in normal C2C12 cells. Interestingly, the same effect was also observed in C57BL/ 6 mice that were fed 10 or $40 \mathrm{mg} / \mathrm{kg} /$ day icariin for 14 days, displaying decreased body weight and enhanced expression of FNDC5, PGC $1 \alpha$, and p-AMPK levels. Other studies reported that icariin was also found to have a protective effect against diet-induced obesity by ameliorating insulin resistance [61,62]. Overall, the preclinical evidence summarized in this review seems to validate the anecdotal capacity of icariin to act on the skeletal muscle and modulate energy metabolism to potentially ameliorate metabolic disease related complications.<smiles>COc1ccc(-c2oc3c(CC=C(C)C)c(OC4OC(CO)[C@@H](O)[C@H](O)[C@H]4O)cc(O)c3c(=O)c2OC2O[C@H](C)[C@@H](O)[C@H](O)[C@H]2O)cc1</smiles>

Figure 6. The chemical structure of icariin, which is commonly found in the extracts of Epimedii Herba. [63].

\subsubsection{Flavonoids, Flavanols and Proanthocyanidins}

Flavones and flavonols (Figure 7) are the most prominent ketone-containing compounds [64]. Furthermore, flavan-3-ols, also known as flavanols, are unique for containing the 2-phenyl-3,4-dihydro-2H-chromen-3-ol skeleton [65]. These compounds encompass catechin, epicatechin gallate, epigallocatechin, epigallocatechin gallate, proanthocyanidins, aflavins, and arubigins $[2,66]$. In fact, increasing literature has reported on the impact of these compounds in improving metabolic function in various preclinical models [33,67]. Reducing oxidative stress and inflammation, as well as regulating insulin signaling path- 
ways such as the PI3K/AKT and energy homeostasis mechanisms such as the AMPK are the prominent effects by which these compounds may improve metabolic function [68].<smiles>O=c1cc(-c2ccccc2)oc2ccccc12</smiles>

(A)<smiles>Oc1cc(O)c2c(c1)O[C@H](c1ccc(O)c(O)c1)[C@H](O)C2</smiles>

(B)<smiles>Oc1cc(O)c2c(c1)OC(c1ccc(O)c(O)c1)C(OC1(c3ccc(O)c(O)c3)Oc3cc(O)cc(O)c3C(O)C1O)C2</smiles>

(C)

Figure 7. An overview of the chemical structure of flavonoids (A), flavanols (B), and proanthocyanidins (C). Briefly these polyphenols are commonly found in in plants and food sources such as wine, tea and chocolate $[69,70]$.

Similarly, data from this review suggest that flavonoids from mulberry (Morus alba L.) leaves can perform the same as metformin (an established glucose lowering drug) in improving muscle glucose uptake and mitochondrial function in L6 muscle cells [31]. These actions were, achieved by activating AMPK and increasing the expression of PGC-1 $\alpha$ and GLUT4 [31]. Importantly, the actions of these flavonoids were consistent with improved mitochondrial function in the skeletal muscle of $d b / d b$ mice. Furthermore, flavan 3-ols fractions derived from cocoa powder were shown to promote lipolysis and mitochondrial biogenesis consistent with increasing $\beta$-oxidation through regulating carnitine palmitoyltransferase 2 (CPT2) expression and mitochondria copy number in mice with metabolic syndrome [35]. As one of the major flavonoids, proanthocyanidins were shown to improve skeletal muscle mitochondrial bioenergetics in obese Zucker fatty rats by reducing citrate synthase activity, oxidative phosphorylation complexes I and II levels, and Nrf1 gene expression, which in turn translated to ameliorated ROS production [33]. These actions were parallel to reduced insulin resistance, improved mitochondrial respiration, mitochondrial oxidative capacity, and fatty acid oxidation, with effective regulation of prominent energy regulation markers such as AMPK, Ppar $\alpha$, and UCP2 [33]. Overall, flavonoids and flavonols show great potential in improving metabolic function by effectively regulating skeletal muscle energy metabolism and mitochondrial bioenergetics in preclinical models of metabolic disease.

\section{Summary and Future Perspective}

It is now widely accepted that a healthy diet is essential to defend the human body against certain types of diseases, especially non-communicable diseases such as obesity, type 2 diabetes, and cardiovascular diseases [71]. Certainly, food sources such as fruits and vegetables have become an attractive source of nutrients and health benefits. In fact, these food sources are known to contain various biological compounds, including polyphenols, that present with enhanced potential beneficial effects in improving metabolic function. Accumulative preclinical evidence suggests that polyphenols can improve metabolic function by effectively regulating energy metabolism, as well as enhancing glucose uptake and mitochondrial function. Here, it was apparent that polyphenolic compounds such as gingerol, icariin, and resveratrol can target the skeletal muscle to regulate energy metabolism and improve mitochondrial function in preclinical models of metabolic syndrome. This is important to establish since it is already known that the pathogenesis of metabolic diseases like diabetes is consistent with skeletal muscle mitochondria deficiency, leading to impaired cellular functions [34-36]. Apparently, in addition to the effective modulation of cellular mechanisms such as insulin signaling and energy regulating pathways through PI3K/AKT and AMPK, these polyphenols seem to target PGC1 $\alpha$ and other mitochondrial functional genes such as TFAM, mfn2, and drp1 to improve mitochondrial bioenergetics. 
These findings also highlight the potential impact naturally derived compounds and micronutrients can have on improving human health by targeting major organ tissues such as the skeletal muscle, as previously discussed [72]. In fact, the summarized data remain essential in developing precise therapeutic targets to be further tested in human subjects and to protect against the rapid rise of metabolic diseases. Although the current study informs on essential preclinical mechanisms that may be involved in the amelioration of metabolic complications, additional experiments and elucidations are still necessary to better understand the therapeutic potential of polyphenols, especially the relevance of their metabolism and bioavailability in the human body.

Author Contributions: Conceptualization, S.X.H.M., P.V.D., and S.E.M.-M.; methodology, S.X.H.M. and K.Z; software, S.X.H.M.; validation, KZ., T.M.N., and P.V.D.; formal analysis, S.X.H.M., and S.E.M.-M.; investigation, S.X.H.M., and K.Z.; resources, S.E.M.-M. and C.J.F.M.; data curation, S.X.H.M., and K.Z; writing-original draft preparation, S.X.H.M. and P.V.D.; writing-review and editing, S.X.H.M., P.V.D., K.Z., C.J.F.M., A.P.K., E.M., T.A.N., T.M.N., B.B.N., S.S.; S.E.M.-M.; visualization, supervision, C.J.F.M., A.P.K., E.M., and S.E.M.-M.; project administration, S.E.M.-M.; funding acquisition, S.E.M.-M. All authors have read and agreed to the published version of the manuscript.

Funding: This work was funded by the National Research Foundation (NRF) of South Africa Thuthuka Programme grant 128296 and NRF support for rated scientist 113674 to SE MazibukoMbeje. Baseline funding from Biomedical Research and Innovation Platform of the South African Medical Research Council (SAMRC) is also acknowledged. Grant holders acknowledge that opinions, findings and conclusions or recommendations expressed in any publication generated by the NRF or SAMRC supported research are those of the authors and that the NRF or SAMRC accepts no liability whatsoever in this regard.

Institutional Review Board Statement: Not applicable.

Informed Consent Statement: Not applicable.

Data Availability Statement: Data related to search strategy, study selection and extraction items will be made available upon request after the manuscript is published.

Acknowledgments: The degree from which this study emanated was funded by South African Medical Research Council through its Division of Research Capacity Development under the internship scholarship program from funding received from the South African National Treasury. The content hereof is the sole responsibility of the authors and does not necessarily represent the official views of the SAMRC or the funders.

Conflicts of Interest: The authors declare no conflict of interest.

Sample Availability: Samples of the compounds are available from the authors.

\section{Abbreviations}

AKT: protein kinase B; AMPK, 5' AMP-activated protein kinase; ATP, adenosine triphosphate; CAT, catalase; drp1, drosophila melanogaster; FFA, free fatty acids; HFD, high fat diet; GLUT 4, glucose transporter type 4; mfn2, mitofusin 2; mtDNA, mitochondrial DNA content; Nrf 1, nuclear factor erythroid-related factor 1 ; PGC1 $\alpha$, peroxisome proliferator-activated receptor $\gamma$ coactivator $1 \alpha$; PI3K, phosphoinositide 3-kinase; ROS, reactive oxygen species; UCP-2, uncoupling protein-2; SIRT 1, sirtuin 1; SOD 1, superoxide dismutase 1; TFAM, mitochondrial transcription factor; GPx, glutathione peroxidase.

\section{References}

1. Fraga, C.G.; Croft, K.D.; Kennedy, D.O.; Tomás-Barberán, F.A. The Effects of Polyphenols and Other Bioactives on Human Health. Food Funct. 2019, 10, 514-528. [CrossRef] [PubMed]

2. Panche, A.N.; Diwan, A.D.; Chandra, S.R. Flavonoids: An overview. J. Nutr. Sci. 2016, 5, 1-15. [CrossRef] [PubMed]

3. Pandey, K.B.; Rizvi, S.I. Plant Polyphenols as Dietary Antioxidants in Human Health and Disease. Oxid. Med. Cell. Longev. 2009, 2, 270-278. [CrossRef] 
4. Di Lorenzo, C.; Colombo, F.; Biella, S.; Stockley, C.; Restani, P. Polyphenols and Human Health: The Role of Bioavailability. Nutrients 2021, 13, 273. [CrossRef] [PubMed]

5. Muller, C.J.F.; Malherbe, C.J.; Chellan, N.; Yagasaki, K.; Miura, Y.; Joubert, E. Potential of rooibos, its major C-glucosyl flavonoids, and Z-2-( $\beta$-D-glucopyranosyloxy)-3-phenylpropenoic acid in prevention of metabolic syndrome. Crit. Rev. Food Sci. Nutr. 2018, 58, 227-246. [CrossRef]

6. Yu, X.; Xiao, J.; Chen, S.; Yu, Y.; Ma, J.; Lin, Y.; Li, R.; Lin, J.; Fu, Z.; Zhou, Q.; et al. Metabolite signatures of diverse Camellia sinensis tea populations. Nat. Commun. 2020,11,1-14. [CrossRef]

7. Marnewick, J.L.; Rautenbach, F.; Venter, I.; Neethling, H.; Blackhurst, D.M.; Wolmarans, P.; MacHaria, M. Effects of rooibos (Aspalathus linearis) on oxidative stress and biochemical parameters in adults at risk for cardiovascular disease. J. Ethnopharmacol. 2011, 133, 46-52. [CrossRef]

8. Beynon, R.A.; Richmond, R.C.; Santos Ferreira, D.L.; Ness, A.R.; May, M.; Smith, G.D.; Vincent, E.E.; Adams, C.; Ala-Korpela, M.; Würtz, P.; et al. Investigating the effects of lycopene and green tea on the metabolome of men at risk of prostate cancer: The ProDiet randomised controlled trial. Int. J. Cancer 2019, 144, 1918-1928. [CrossRef]

9. Dludla, P.V.; Johnson, R.; Mazibuko-Mbeje, S.E.; Muller, C.J.F.; Louw, J.; Joubert, E.; Orlando, P.; Silvestri, S.; Chellan, N.; Nkambule, B.B.; et al. Fermented rooibos extract attenuates hyperglycemia-induced myocardial oxidative damage by improving mitochondrial energetics and intracellular antioxidant capacity. S. Afr. J. Bot. 2020, 131, 143-150. [CrossRef]

10. Mazibuko-Mbeje, S.E.; Dludla, P.V.; Johnson, R.; Joubert, E.; Louw, J.; Ziqubu, K.; Tiano, L.; Silvestri, S.; Orlando, P.; Opoku, A.R.; et al. Aspalathin, a natural product with the potential to reverse hepatic insulin resistance by improving energy metabolism and mitochondrial respiration. PLoS ONE 2019, 14, e0216172. [CrossRef] [PubMed]

11. Mazibuko-Mbeje, S.E.; Ziqubu, K.; Dludla, P.V.; Tiano, L.; Silvestri, S.; Orlando, P.; Nyawo, T.A.; Louw, J.; Kappo, A.P.; Muller, C.J. Isoorientin ameliorates lipid accumulation by regulating fat browning in palmitate-exposed 3T3-L1 adipocytes. Metab. Open. 2020, 6, 100037. [CrossRef]

12. Mazibuko-Mbeje, S.E.; Dludla, P.V.; Roux, C.; Johnson, R.; Ghoor, S.; Joubert, E.; Louw, J.; Opoku, A.R.; Muller, C.J. Aspalathinenriched green rooibos extract reduces hepatic insulin resistance by modulating PI3K/AKT and AMPK pathways. Int. J. Mol. Sci. 2019, 20, 633. [CrossRef] [PubMed]

13. Luo, Q.; Zhang, J.-R.; Li, H.-B.; Wu, D.-T.; Geng, F.; Corke, H.; Wei, X.-L.; Gan, R.-Y. Green Extraction of Antioxidant Polyphenols from Green Tea (Camellia sinensis). Antioxidants 2020, 9, 785. [CrossRef]

14. Chen, L.L.; Zhang, H.H.; Zheng, J.; Hu, X.; Kong, W.; Hu, D.; Wang, S.X.; Zhang, P. Resveratrol attenuates high-fat diet-induced insulin resistance by influencing skeletal muscle lipid transport and subsarcolemmal mitochondrial $\beta$-oxidation. Metabolism 2011, 60, 1598-1609. [CrossRef] [PubMed]

15. Lainampetch, J.; Panprathip, P.; Phosat, C.; Chumpathat, N.; Prangthip, P.; Soonthornworasiri, N.; Puduang, S.; Wechjakwen, N.; Kwanbunjan, K. Association of Tumor Necrosis Factor Alpha, Interleukin 6, and C-Reactive Protein with the Risk of Developing Type 2 Diabetes: A Retrospective Cohort Study of Rural Thais. J. Diabetes Res. 2019, 2019. [CrossRef] [PubMed]

16. Truong, V.-L.; Jun, M.; Jeong, W.-S. Role of resveratrol in regulation of cellular defense systems against oxidative stress. BioFactors 2018, 44, 36-49. [CrossRef] [PubMed]

17. Huang, Y.; Zhu, X.; Chen, K.; Lang, H.; Zhang, Y.; Hou, P.; Ran, L.; Zhou, M.; Zheng, J.; Yi, L.; et al. Resveratrol prevents sarcopenic obesity by reversing mitochondrial dysfunction and oxidative stress via the PKA/LKB1/AMPK pathway. Aging 2019, 11, 2217-2240. [CrossRef] [PubMed]

18. Di Meo, S.; Iossa, S.; Venditti, P. Skeletal muscle insulin resistance: Role of mitochondria and other ROS sources. J. Endocrinol. 2017, 233, R15-R42. [CrossRef] [PubMed]

19. Coudray, C.; Fouret, G.; Lambert, K.; Ferreri, C.; Rieusset, J.; Blachnio-Zabielska, A.; Lecomte, J.; Ebabe Elle, R.; Badia, E.; Murphy, M.P.; et al. A mitochondrial-targeted ubiquinone modulates muscle lipid profile and improves mitochondrial respiration in obesogenic diet-fed rats. Br. J. Nutr. 2016, 115, 1155-1166. [CrossRef]

20. Jørgensen, W.; Rud, K.A.; Mortensen, O.H.; Frandsen, L.; Grunnet, N.; Quistorff, B. Your mitochondria are what you eat: A high-fat or a high-sucrose diet eliminates metabolic flexibility in isolated mitochondria from rat skeletal muscle. Physiol. Rep. 2017, 5. [CrossRef]

21. Price, N.L.; Gomes, A.P.; Ling, A.J.Y.; Duarte, F.V.; Martin-Montalvo, A.; North, B.J.; Agarwal, B.; Ye, L.; Ramadori, G.; Teodoro, J.S.; et al. SIRT1 is required for AMPK activation and the beneficial effects of resveratrol on mitochondrial function. Cell Metab. 2012, 15, 675-690. [CrossRef]

22. Sharma, S.; Tripathi, P.; Sharma, J.; Dixit, A. Flavonoids modulate tight junction barrier functions in hyperglycemic human intestinal Caco-2 cells. Nutrition 2020, 78, 110792. [CrossRef] [PubMed]

23. Higashida, K.; Kim, S.H.; Jung, S.R.; Asaka, M.; Holloszy, J.O.; Han, D.H. Effects of Resveratrol and SIRT1 on PGC-1 $\alpha$ Activity and Mitochondrial Biogenesis: A Reevaluation. PLoS Biol. 2013, 11, e1001603. [CrossRef]

24. Zhou, X.; Zuo, S.; Xin, W. miR-27b overexpression improves mitochondrial function in a Sirt1-dependent manner. J. Physiol. Biochem. 2015, 71, 753-762. [CrossRef] [PubMed]

25. Li, Y.; Tran, V.H.; Kota, B.P.; Nammi, S.; Duke, C.C.; Roufogalis, B.D. Preventative effect of zingiber officinale on insulin resistance in a high-fat high-carbohydrate diet-fed rat model and its mechanism of action. Basic Clin. Pharmacol. Toxicol. 2014, 115, $209-215$. [CrossRef] 
26. Mutlur Krishnamoorthy, R.; Carani Venkatraman, A. Polyphenols activate energy sensing network in insulin resistant models. Chem. Biol. Interact. 2017, 275, 95-107. [CrossRef]

27. Modi, S.; Yaluri, N.; Kokkola, T.; Laakso, M. Plant-derived compounds strigolactone GR24 and pinosylvin activate SIRT1 and enhance glucose uptake in rat skeletal muscle cells. Sci. Rep. 2017, 7. [CrossRef] [PubMed]

28. Chen, S.Q.; Ding, L.N.; Zeng, N.X.; Liu, H.M.; Zheng, S.H.; Xu, J.W.; Li, R.M. Icariin induces irisin/FNDC5 expression in C2C12 cells via the AMPK pathway. Biomed. Pharmacother. 2019, 115. [CrossRef]

29. Meng, Q.; Qi, X.; Fu, Y.; Chen, Q.; Cheng, P.; Yu, X.; Sun, X.; Wu, J.; Li, W.; Zhang, Q.; et al. Flavonoids extracted from mulberry (Morus alba L.) leaf improve skeletal muscle mitochondrial function by activating AMPK in type 2 diabetes. J. Ethnopharmacol. 2020, 248, 112326. [CrossRef] [PubMed]

30. Lagouge, M.; Argmann, C.; Gerhart-Hines, Z.; Meziane, H.; Lerin, C.; Daussin, F.; Messadeq, N.; Milne, J.; Lambert, P.; Elliott, P.; et al. Resveratrol Improves Mitochondrial Function and Protects against Metabolic Disease by Activating SIRT1 and PGC-1 $\alpha$. Cell 2006, 127, 1109-1122. [CrossRef] [PubMed]

31. Zheng, J.; Chen, L.L.; Zhang, H.H.; Hu, X.; Kong, W.; Hu, D. Resveratrol improves insulin resistance of catch-up growth by increasing mitochondrial complexes and antioxidant function in skeletal muscle. Metabolism 2012, 61, 954-965. [CrossRef]

32. Haohao, Z.; Guijun, Q.; Juan, Z.; Wen, K.; Lulu, C. Resveratrol improves high-fat diet induced insulin resistance by rebalancing subsarcolemmal mitochondrial oxidation and antioxidantion. J. Physiol. Biochem. 2015, 71, 121-131. [CrossRef]

33. Pajuelo, D.; Fernández-Iglesias, A.; Díaz, S.; Quesada, H.; Arola-Arnal, A.; Bladé, C.; Salvadó, J.; Arola, L. Improvement of mitochondrial function in muscle of genetically obese rats after chronic supplementation with proanthocyanidins. J. Agric. Food Chem. 2011, 59, 8491-8498. [CrossRef] [PubMed]

34. Casanova, E.; Baselga-Escudero, L.; Ribas-Latre, A.; Cedó, L.; Arola-Arnal, A.; Pinent, M.; Bladé, C.; Arola, L.; Salvadó, M.J. Chronic intake of proanthocyanidins and docosahexaenoic acid improves skeletal muscle oxidative capacity in diet-obese rats. $J$. Nutr. Biochem. 2014, 25, 1003-1010. [CrossRef] [PubMed]

35. Watanabe, N.; Inagawa, K.; Shibata, M.; Osakabe, N. Flavan-3-Ol Fraction from Cocoa Powder Promotes Mitochondrial Biogenesis in Skeletal Muscle in Mice. Lipids Health Dis. 2014, 13, 1-8. [CrossRef] [PubMed]

36. Shrikanta, A.; Kumar, A.; Govindaswamy, V. Resveratrol content and antioxidant properties of underutilized fruits. J. Food Sci. Technol. 2015, 52, 383-390. [CrossRef]

37. Marier, J.F.; Vachon, P.; Gritsas, A.; Zhang, J.; Moreau, J.P.; Ducharme, M.P. Metabolism and disposition of resveratrol in rats: Extent of absorption, glucuronidation, and enterohepatic recirculation evidenced by a linked-rat model. J. Pharmacol. Exp. Ther. 2002, 302, 369-373. [CrossRef] [PubMed]

38. Resveratrol ICAS:501-36-0 | Price: \$30/20 mg | Manufacturer ChemFaces. Available online: http://www.chemfaces.com/natural/ Resveratrol-CFN98791.html (accessed on 31 March 2021).

39. Wang, Q.; Wei, Q.; Yang, Q.; Cao, X.; Li, Q.; Shi, F.; Tong, S.S.; Feng, C.; Yu, Q.; Yu, J.; et al. A novel formulation of [6]-gingerol: Proliposomes with enhanced oral bioavailability and antitumor effect. Int. J. Pharm. 2018, 535, 308-315. [CrossRef]

40. Xu, Y.; Wang, Q.; Feng, Y.; Firempong, C.K.; Zhu, Y.; Omari-Siaw, E.; Zheng, Y.; Pu, Z.; Xu, X.; Yu, J. Enhanced oral bioavailability of [6]-Gingerol-SMEDDS: Preparation, in vitro and in vivo evaluation. J. Funct. Foods 2016, 27, 703-710. [CrossRef]

41. Madkor, H.R.; Mansour, S.W.; Ramadan, G. Modulatory effects of garlic, ginger, turmeric and their mixture on hyperglycaemia, dyslipidaemia and oxidative stress in streptozotocin-nicotinamide diabetic rats. Br. J. Nutr. 2010, 105, 1210-1217. [CrossRef]

42. Lin, C.B.; Lin, C.C.; Tsay, G.J. 6-gingerol inhibits growth of colon cancer cell LoVo via induction of G2/M arrest. Evid. Based Complement. Altern. Med. 2012, 2012. [CrossRef] [PubMed]

43. Dugasani, S.; Rao Pichika, M.; Nadarajah, V.D.; Katyayani Balijepalli, M.; Tandra, S.; Narsimha Korlakunta, J. Comparative antioxidant and anti-inflammatory effects of [6]-gingerol, [8]-gingerol, [10]-gingerol and [6]-shogaol. J. Ethnopharmacol. 2010, 127, 515-520. [CrossRef] [PubMed]

44. Sharma, S.; Yadav, A. Gingerol Derivatives as $14 \alpha$-demethylase Inhibitors: Design and Development of Natural, Safe Antifungals for Immune-compromised Patients. Lett. Drug Des. Discov. 2020, 17, 918-928. [CrossRef]

45. Li, Y.; Tran, V.; Duke, C.; Roufogalis, B. Gingerols of Zingiber officinale Enhance Glucose Uptake by Increasing Cell Surface GLUT4 in Cultured L6 Myotubes. Planta Med. 2012, 78, 1549-1555. [CrossRef] [PubMed]

46. Samad, M.B.; Mohsin, M.N.A.B.; Razu, B.A.; Hossain, M.T.; Mahzabeen, S.; Unnoor, N.; Muna, I.A.; Akhter, F.; Kabir, A.U.; Hannan, J.M.A. [6]-Gingerol, from Zingiber officinale, potentiates GLP-1 mediated glucose-stimulated insulin secretion pathway in pancreatic $\beta$-cells and increases RAB8/RAB10-regulated membrane presentation of GLUT4 transporters in skeletal muscle to improve hyperglycemia in Leprdb/db type 2 diabetic mice. BMC Complement. Altern. Med. 2017, 17. [CrossRef]

47. 6-Gingerol |CAS:23513-14-6 | Price: \$80/20 mg | Manufacturer ChemFaces. Available online: http://www.chemfaces.com/ natural/6-Gingerol-CFN99931.html (accessed on 31 March 2021).

48. Alrawaiq, N.S.; Abdullah, A. A review of flavonoid quercetin: Metabolism, bioactivity and antioxidant properties. Int. J. Pharm Tech Res. 2014, 6, 933-941.

49. Ahmed, O.M.; Ahmed, A.A.; Fahim, H.I.; Zaky, M.Y. Quercetin and naringenin abate diethylnitrosamine/acetylaminofluorene-induced hepatocarcinogenesis in Wistar rats: The roles of oxidative stress, inflammation and cell apoptosis. Drug Chem. Toxicol. 2019. [CrossRef]

50. Tu, B.; Liu, Z.J.; Chen, Z.F.; Ouyang, Y.; Hu, Y.J. Understanding the structure-activity relationship between quercetin and naringenin: In vitro. RSC Adv. 2015, 5, 106171-106181. [CrossRef] 
51. Ke, J.Y.; Banh, T.; Hsiao, Y.H.; Cole, R.M.; Straka, S.R.; Yee, L.D.; Belury, M.A. Citrus flavonoid naringenin reduces mammary tumor cell viability, adipose mass, and adipose inflammation in obese ovariectomized mice. Mol. Nutr. Food Res. 2017, 61. [CrossRef] [PubMed]

52. Alam, M.; Kauter, K.; Brown, L. Naringin Improves Diet-Induced Cardiovascular Dysfunction and Obesity in High Carbohydrate, High Fat Diet-Fed Rats. Nutrients 2013, 5, 637-650. [CrossRef] [PubMed]

53. Quercetin |CAS:117-39-5 | Price: \$40/20 mg / Manufacturer ChemFaces. Available online: http://www.chemfaces.com/natural/ Quercetin-CFN99272.html (accessed on 31 March 2021).

54. Naringenin I CAS:480-41-1 I Price: \$30/20 mg | Manufacturer ChemFaces. Available online: http://www.chemfaces.com/natural/ Naringenin-CFN98742.html (accessed on 21 March 2021).

55. Eräsalo, H.; Hämäläinen, M.; Leppänen, T.; Mäki-Opas, I.; Laavola, M.; Haavikko, R.; Yli-Kauhaluoma, J.; Moilanen, E. Natural Stilbenoids Have Anti-Inflammatory Properties in Vivo and Down-Regulate the Production of Inflammatory Mediators NO, IL6, and MCP1 Possibly in a PI3K/Akt-Dependent Manner. J. Nat. Prod. 2018, 81, 1131-1142. [CrossRef] [PubMed]

56. Wahedi, H.M.; Ahmad, S.; Abbasi, S.W. Stilbene-based natural compounds as promising drug candidates against COVID-19. J. Biomol. Struct. Dyn. 2020. [CrossRef] [PubMed]

57. Pinosylvin | CAS:22139-77-1 | Price: \$288/20 mg | Manufacturer ChemFaces. Available online: http:/ /www.chemfaces.com/ natural/Pinosylvin-CFN98203.html (accessed on 31 March 2021).

58. Pecyna, P.; Wargula, J.; Murias, M.; Kucinska, M. More Than Resveratrol: New Insights into Stilbene-Based Compounds. Biomolecules 2020, 10, 1111. [CrossRef] [PubMed]

59. Wang, Y.; Wang, Y.S.; Song, S.L.; Liang, H.; Ji, A.G. Icariin inhibits atherosclerosis progress in Apoe null mice by downregulating CX3CR1 in macrophage. Biochem. Biophys. Res. Commun. 2016, 470, 845-850. [CrossRef] [PubMed]

60. Hu, Y.; Sun, B.; Liu, K.; Yan, M.; Zhang, Y.; Miao, C.; Ren, L. Icariin Attenuates High-cholesterol Diet Induced Atherosclerosis in Rats by Inhibition of Inflammatory Response and p38 MAPK Signaling Pathway. Inflammation 2016, 39, 228-236. [CrossRef] [PubMed]

61. Han, Y.; Jung, H.W.; Park, Y.K. Effects of Icariin on insulin resistance via the activation of AMPK pathway in C2C12 mouse muscle cells. Eur. J. Pharmacol. 2015, 758, 60-63. [CrossRef] [PubMed]

62. Icariin I CAS:489-32-7 | Price: \$30/20 mg I Manufacturer ChemFaces. Available online: http://www.chemfaces.com/natural/ Icariin-CFN99554.html (accessed on 31 March 2021).

63. Han, L.Y.; Wu, Y.L.; Zhu, C.Y.; Wu, C.S.; Yang, C.R. Improved pharmacokinetics of icariin (ica) within formulation of pegplla/pdla-pnipam polymeric micelles. Pharmaceutics 2019, 11, 51. [CrossRef] [PubMed]

64. Raman, G.; Shams-White, M.; Avendano, E.E.; Chen, F.; Novotny, J.A.; Cassidy, A. Dietary intakes of flavan-3-ols and cardiovascular health: A field synopsis using evidence mapping of randomized trials and prospective cohort studies. Syst. Rev. 2018, 7, 100. [CrossRef]

65. Lee, M.K.; Kim, H.W.; Lee, S.H.; Kim, Y.J.; Asamenew, G.; Choi, J.; Lee, J.W.; Jung, H.A.; Yoo, S.M.; Kim, J.B. Characterization of catechins, theaflavins, and flavonols by leaf processing step in green and black teas (Camellia sinensis) using UPLC-DADQToF/MS. Eur. Food Res. Technol. 2019, 245, 997-1010. [CrossRef]

66. Oliveira, J.; Mateus, N.; de Freitas, V. Flavanols: Catechins and proanthocyanidins. In Natural Products: Phytochemistry, Botany and Metabolism of Alkaloids, Phenolics and Terpenes; Springer: Berlin/Heidelberg, Germany, 2013; pp. 1753-1801. ISBN 9783642221446.

67. Legeay, S.; Rodier, M.; Fillon, L.; Faure, S.; Clere, N. Epigallocatechin Gallate: A Review of Its Beneficial Properties to Prevent Metabolic Syndrome. Nutrients 2015, 7, 5443-5468. [CrossRef] [PubMed]

68. Flavone I CAS:525-82-6 | Price: \$30/20 mg | Manufacturer ChemFaces. Available online: http://www.chemfaces.com/natural/ Flavone-CFN70130.html (accessed on 31 March 2021).

69. Proanthocyanidins I CAS:4852-22-6 | Price: $\$ 70 / 20 \mathrm{mg}$ | Manufacturer ChemFaces. Available online: http://www.chemfaces.com/ natural/Proanthocyanidins-CFN99556.html (accessed on 21 March 2021).

70. Nair, H.B.; Sung, B.; Yadav, V.R.; Kannappan, R.; Chaturvedi, M.M.; Aggarwal, B.B. Delivery of antiinflammatory nutraceuticals by nanoparticles for the prevention and treatment of cancer. Biochem. Pharmacol. 2010, 80, 1833-1843. [CrossRef] [PubMed]

71. Koch, W. Dietary polyphenols-important non-nutrients in the prevention of chronic noncommunicable diseases. A systematic review. Nutrients 2019, 11, 1039. [CrossRef] [PubMed]

72. Moretti, A.; Paoletta, M.; Liguori, S.; Bertone, M.; Toro, G.; Iolascon, G. Choline: An Essential Nutrient for Skeletal Muscle. Nutrients 2020, 12, 2144. [CrossRef] [PubMed] 